EDUKACJA MIĘDZYKULTUROWA

\title{
Zadania szkoły i nauczycieli na terenach występowania dialektu - przykład Górnego Śląska
}

Zróżnicowanie ludzi i tworzonych przez nich kultur jest bogactwem i szansą na rozwój jednostek i społeczeństw, niestety często też bywa przyczyną konfliktów Alina Szczurek-Boruta ${ }^{1}$

Streszczenie: Celem tego opracowania jest - w odniesieniu do koncepcji edukacji międzykulturowej i regionalnej - określenie zadań szkoły i nauczycieli na terenach występowania dialektu. Artykuł opisuje językowy aspekt wielokulturowości śląskich szkół. Na podstawie literatury pedagogicznej i socjologicznej autorka formułuje tezę, że zróżnicowanie językowe jest bogactwem i szansą na rozwój uczniów i nauczycieli, stwarza możliwość uczenia się międzykulturowego, lecz może być też przyczyną konfliktów. Materiał badawczy, do którego odnoszą się podjęte rozważania, został zebrany za pomocą metody biograficznej z wykorzystaniem techniki wywiadu narracyjnego. Wyniki przeprowadzonych badań potwierdziły sformułowaną tezę. Pozwalają określić zadania szkoły i nauczycieli na terenach występowania dialektu. Można odnieść je również do innych obszarów, gdzie ludność autochtoniczna silnie identyfikuje się z dialektem i kulturą regionalną w ogóle. Choć artykuł pomija kwestię wprowadzenia obowiązkowej nauki śląskiego w szkołach, na tle takich dążeń podjęta tematyka wydaje się szczególnie aktualna.

Słowa kluczowe: język polski, dialekt, gwara, edukacja szkolna, tożsamość językowa

1 A. Szczurek-Boruta: Doświadczenia spoteczne w przygotowaniu przysztych nauczycieli do pracy w warunkach wielokulturowości. Torun 2013, WEiNoE UŚ, Wydawnictwo Adam Marszałek, s. 134. 


\section{Wstęp}

W serii wydawniczej „Edukacja Międzykulturowa”, ukazującej się od 1992 roku w cieszyńskim ośrodku naukowym, wielokrotnie poruszano kwestie związane z językiem, a w 2004 roku poświęcono temu zagadnieniu cały tom². Język stanowi niezwykle obszerne pole badań i rozważań naukowych, ponieważ jest swoistym pars pro toto całej kultury.

Występowanie dialektu na danym terenie tworzy specyficzną sytuację edukacyjną. Zróżnicowanie językowe jest bogactwem i szansą na rozwój uczniów i nauczycieli, stwarza możliwość uczenia się międzykulturowego, lecz może być też przyczyną konfliktów. Wykorzystanie potencjału takiego środowiska wymaga od pedagogów szczególnej samoświadomości oraz umiejętności reagowania na antagonizmy rodzące się w grupie i uprzedzenia wynoszone z domu rodzinnego uczniów.

Celem tego artykułu jest wskazanie zadań szkoły i nauczycieli na terenach, na których występuje gwara, w odniesieniu do koncepcji edukacji międzykulturowej i regionalnej. W Polsce występują duże różnice między obszarami dialektalnymi. W tekście tym posłużę się przykładem Górnego Śląska, pomijając kwestie dotyczące mniejszości niemieckiej na Opolszczyźnie. Materiał badawczy, do którego odnoszą się poniższe rozważania, został zebrany za pomocą metody biograficznej z wykorzystaniem techniki wywiadu narracyjnego.

\section{Język - dialekt - gwara}

Język można definiować jako „system znaków (prymarnie dźwiękowych, wtórnie pisanych i in.) służący do porozumiewania się w obrębie danej społeczności”3. Jego wewnętrzne zróżnicowanie jest spowodowane szeregiem różnych czynników - geograficznych, historycznych, socjalnych i in.

Jedną z odmian języka są dialekty terytorialne, do których w Polsce zaliczają się: śląski, małopolski, wielkopolski, mazowiecki. Kaszubski, uważany

2 T. Lewowicki, J. Urban, A. Szczypka-Rusz (red.): Język, komunikacja i edukacja w spotecznościach wielokulturowych. Cieszyn - Warszawa 2004, Uniwersytet Śląski w Cieszynie, Wyższa Szkoła Pedagogiczna ZNP w Warszawie.

3 K. Polański, M. Jurkowski (red.): Encyklopedia językoznawstwa ogólnego. Wrocław 1993, Wyd. Ossolineum, s. 240. 
wcześniej za dialekt, w 2005 roku zyskał rangę języka regionalnego ${ }^{4}$. Na Kresach Wschodnich II Rzeczypospolitej występowały też dialekty kresowe. Jak zauważa Janusz Strutyński: „Dialekt terytorialny przeciwstawia się językowi ogólnopolskiemu właściwościami fonetycznymi, leksykalnymi, niekiedy również gramatycznymi i składniowymi" ${ }^{\text {. }}$

W obrębie dialektu występują gwary, czyli jego odmiany o mniejszym zasięgu terytorialnym. Gwara jest kojarzona ze środowiskiem wiejskim zarówno w potocznej świadomości, jak i w opinii wielu językoznawców. Przykład Śląska obala tę tezę. Śląskich słów, zwrotów, a niekiedy całych wypowiedzi używają między sobą w codziennej komunikacji pracownicy instytucji skupiających głównie osoby z wyższym wykształceniem, jak sądy, szpitale, urzędy miejskie. Rozmowa z petentem po śląsku również nie jest rzadkością. Od września 2012 roku do czerwca 2013 roku na 113 instytucjach w województwie śląskim i opolskim zawisły tabliczki z napisem „Godomy po ślonsku" oficjalnie informujące, że w danym miejscu można załatwić sprawę, mówiąc gwarą ${ }^{6}$. Do akcji przyłączyły się m.in. sklepy, restauracje, urzędy, plebanie, a także szkoły.

\section{Język - rzeczywistość - tożsamość}

Relacja między językiem a rzeczywistością jest jednym z klasycznych dylematów nauk humanistycznych. Metateoria Sapira-Whorfa mówi, że „nasza percepcja rzeczywistości i obraz świata zależą od struktury języka, w którego ramach ich dokonujemy. Myślenie werbalne staje się rzeczywistością na gruncie i za pomocą określonego języka. Myślimy, tak jak mówimy, i jednocześnie mówimy, tak jak myślimy"7. Przeciwnicy tego stanowiska twierdzą,

4 A. Kożyczkowska, K. Kossak-Główczewski: Edukacja języka i kultury na terenie Kaszub. Wybrane aspekty. W: T. Lewowicki, J. Nikitorowicz, A. Szczurek-Boruta (red.): Szkoty dla mniejszości narodowych i społeczności kaszubskiej w Polsce - stan, problemy i perspektywy. Warszawa - Cieszyn - Białystok 2013, WSP ZNP, WEiNoE UŚ, UwB, SWEM, s. 172.

5 J. Strutyński: Gramatyka polska. Kraków 2002, Wyd. Tomasz Strutyński, s. 25.

6 PAP: Tabliczki „Godomy po ślasku” niebawem w firmach, sklepach $i$ urzędach. W: http://www.dziennikzachodni.pl/artykul/668279,tabliczki-godomy-po-slasku-niebawem-w-firmach-sklepach-i-urzedach,id,t.html (27.08.2014).

7 J. Nikitorowicz: Kreowanie tożsamości dziecka. Wyzwania edukacji międzykulturowej. Gdańsk 2005, GWP, s. 69. 
że język tylko odwzorowuje rzeczywistość obiektywną, istniejącą niezależnie od niego.

Rozstrzygnięcie tego teoretycznego dylematu niesie ze sobą praktyczne implikacje w życiu społecznym, także w edukacji. Pedagodzy poprzez obserwacje zachowań językowych swoich wychowanków mogą wnioskować na temat ich postrzegania rzeczywistości kształtowanego przez najbliższe środowisko, a poprzez uczenie nowych nawyków językowych - zmieniać postrzeganie świata i samych siebie.

Tożsamość jest częścią rzeczywistości, a więc jej relacje z językiem są tak samo sporną kwestią. Stanowiska różnych pedagogów i rozmaite działania edukacyjne można opisać słowami brytyjskich badaczek: „nie uważamy języka za czynnik determinujący tożsamość, ani też tożsamości za kształtującą język, lecz raczej widzimy obydwa te elementy jako wzajemnie się konstytuujące"8.

W pedagogice - podobnie jak w filozofii i psychologii - przyjmuje się, że: „Tożsamość nie bywa nigdy zwyczajnie dana, tzn. nie pojawia się automatycznie, ale stanowi rezultat trwałego wysiłku egzystencjalnego" W pedagogice międzykulturowej mówi się o tożsamości jako ustawicznym zadaniu $^{10}$ - zarówno wychowawcy, jak i wychowanka ${ }^{11}$. Nie inaczej jest z tożsamością językową, której najwęższym rodzajem jest identyfikacja z grupą kulturową (subkulturą) poprzez gwarę, dialekt, slang ${ }^{12}$.

8 G. Valentine, D. Sporton, K. B. Nielsen: Migracja a postugiwanie się językiem: miejsca spotkań, tożsamości, przynależność. Tłum. J. Popowski, W: A. Grudzińska, K. Kubin (red.): Szkoła wielokulturowa - organizacja pracy i metody nauczania. Wybór tekstów. Warszawa 2010, Forum na rzecz Różnorodności Społecznej, s. 136.

9 A. Szczurek-Boruta: Zadania rozwojowe mtodzieży i edukacyjne warunki ich wypetniania w środowiskach zróżnicowanych kulturowo i gospodarczo. Studium pedagogiczne. Katowice 2007, UŚ, s. 121.

10 J. Nikitorowicz: Kreowanie tożsamości dziecka. Wyzwania edukacji międzykulturowej. cyt. wyd., s. 61.

11 A. Szczurek-Boruta: Szkoła i jej rola w kształtowaniu tożsamości młodzieży. W: T. Lewowicki, W. Ogniewjuk, E. Ogrodzka-Mazur, S. Sysojewa (red.): Wielokulturowość i edukacja. Warszawa - Cieszyn - Kijów 2014, WSP ZNP, WEiNoE UŚ, Uniwersytet im. Borysa Grinczenki, s. 286.

12 S. Paleczny: Socjologia tożsamości. Kraków 2008, Krakowskie Towarzystwo Edukacyjne, Oficyna Wydawnicza AFM, s. 54. 


\section{Nobilitacja dialektów i języków regionalnych we współczesnej Europie}

Powojenne tendencje w PRL nie sprzyjały kultywowaniu dialektów i gwar w przestrzeni publicznej. Od czasu transformacji ustrojowej obserwuje się znaczne ożywienie ruchów językowych. Podobne zmiany zachodzą w całej Europie. Poniekąd jest to reakcja na sytuację opisaną przez Jerzego Nikitorowicza: „Współcześnie wiele ludów tubylczych poddawanych jest silnym oddziaływaniom kulturowo-edukacyjnym, co w efekcie powoduje przejmowanie języka urzędowego i rezygnację z mowy ojczystej"13. Silna korelacja między językiem używanym w domu a tożsamością narodową i etniczną, potwierdzona przez liczne badania naukowe ${ }^{14}$, jest uzasadnieniem dążeń grup mniejszościowych do zachowania swych specyficznych systemów językowych, którymi posługują się od wieków.

Kierunek zmian przejawia się w prawodawstwie Rady Europy, Unii Europejskiej i państw członkowskich. Europejska Karta języków regionalnych lub mniejszościowych, sporządzona w Strasburgu dnia 5 listopada 1992 r. $^{15}$ powstała w celu ochrony i promocji języków regionalnych i mniejszościowych w różnych krajach i regionach Europy. Przez Polskę została przyjęta w 2009 roku. W 1995 roku uchwalono Konwencje ramowa o ochronie mniejszości narodowych ${ }^{16}$, której przestrzeganie Polska zadeklarowała (nie ratyfikując jej) w 2001 roku. Sejm Rzeczypospolitej 6 stycznia 2005 roku uchwalił Ustawe o mniejszościach narodowych $i$ etnicznych oraz o języku regional-

13 J. Nikitorowicz: Grupy etniczne w wielokulturowym świecie. Sopot 2010, GWP, s. 27.

14. M.in. Z. Kurcz: Mniejszość polska na Wileńszczyźnie. Studium socjologiczne. Wrocław 2005, UWr; M. Sobecki: Kultura symboliczna a tożsamość. Studium tożsamości kulturowej Polaków na Grodzieńszczyźnie z perspektywy edukacji międzykulturowej. Białystok 2007, Trans Humana; M. M. Urlińska: Szkoła polska na obczyźnie wobec dylematów tożsamościowych. Toruń 2007, UMK; B. Grabowska: Poczucie tożsamości mtodzieży uczacej się w szkołach z polskim językiem nauczania na Białorusi, Ukrainie $i$ w Republice Czeskiej - studium porównawcze. Toruń 2013, Wydawnictwo Adam Marszałek.

15 Europejska Karta języków regionalnych lub mniejszościowych, sporządzona w Strasburgu dnia 5 listopada 1992 r. (Dz. U. 2009, nr 137 poz. 1121).

16 Konwencja ramowa o ochronie mniejszości narodowych, sporządzona $w$ Strasburgu dnia 1 lutego 1995 r. (Dz. U. 2002, nr 22 poz. 209). 
$n y m^{17}$. W ustawie tej kaszubskiemu przyznano status języka regionalnego. Dla śląskiego taki sam status chce wywalczyć spora i silna grupa działaczy śląskich. W Ustawie o systemie oświaty ${ }^{18}$ jest mowa o podtrzymywaniu poczucia tożsamości językowej (obok narodowej, etnicznej i religijnej) oraz tradycji i kultury regionalnej. Przekłada się to na treści podstaw programowych Ministerstwa Edukacji Narodowej. W praktyce wiele zależy od kultury szkoły i zaangażowania grona pedagogicznego w realizację zapisów prawnych.

\section{Obszary gwarowe w obrębie dialektu śląskiego}

Granice Górnego Śląska nie pokrywają się z podziałem administracyjnym Polski, wychodząc nawet poza południową granicę państwa, dlatego opis sytuacji edukacyjnej i zadań szkoły poprzedzę określeniem terytorium, do którego będą odnosiły się dalsze rozważania.

Podział Śląska na subregiony jest kwestią sporną. Różnice kulturowe, językowe, gospodarcze pomiędzy poszczególnymi obszarami są łatwo dostrzegalne, jednak podział nie jest oczywisty. Alfred Zaręba wyróżnił następujące obszary gwarowe w obrębie dialektu śląskiego:

- Śląsk południowy

1. jabłonkowski

2. cieszyński

3. pogranicze śląsko-laskie

- Śląsk środkowy

4. okręg gliwicki centralny

4a. pogranicze śląsko-małopolskie

4b. pogranicze gliwicko-małopolskie

5. prudnicki

- Śląsk północny

6. niemodliński

7. opolski

8. kluczborski ${ }^{19}$.

17 Ustawa $z$ dnia 6 stycznia 2005 r. o mniejszościach narodowych i etnicznych oraz o języku regionalnym (Dz. U. 2005, nr 17 poz. 141).

18 Ustawa z dnia 7 września 1991 r. o systemie oświaty (Dz. U. 2004, nr 256 poz. 2572).

19 I. Winiarska: Zasięg terytorialny i podziały dialektu ślaskiego. W: http://www. gwarypolskie.uw.edu.pl/index.php?option=com_content\&task=view\&id=854\&Itemid=19 (29.08.2014). 
Poza obszarem gwarowym dialektu śląskiego znajduje się Dolny Śląsk, gdyż z powodu powojennych przesiedleń mieszkająca tam ludność pochodzi z różnych rejonów II Rzeczypospolitej, przy czym większość w ramach repatriacji przybyła z Wołynia, Podola i innych rejonów Kresów Wschodnich. Na Dolnym Śląsku i pozostałych Ziemiach Odzyskanych ludzie posługują się najczystszą polszczyzną ${ }^{20}$, tzn. wolną od naleciałości gwarowych, najbliższą językowi ogólnopolskiemu, którego słownictwo, gramatykę, wymowę, ortografię i interpunkcję reguluje Rada Języka Polskiego przy Prezydium Polskiej Akademii Nauk. Należy jednak zauważyć, że aktywne działania kulturalne drugiego i trzeciego pokolenia Kresowiaków zmierzają do ożywiania dialektów kresowych.

\section{Założenia metodologiczne}

Badania (auto)biograficzne charakteryzują się szczególnym potencjałem wykorzystywanym w pedagogice „przede wszystkim w poznawaniu procesów wychowawczych/edukacyjnych - postrzeganych całościowo lub w wybranych fazach życia człowieka i różnych aspektach, jak również rozumieniu różnorakich złożonych kontekstów tych procesów" ${ }^{21}$. Badania dotyczące zadań szkoły i nauczycieli na terenach występowania dialektu śląskiego skupiały się na aspekcie funkcjonowania językowego w wieku szkolnym. Wywiady narracyjne przeprowadzono z pięcioma osobami: kobietą (ur. 1985 r.) ze wsi ze Śląska północnego - opolskiego, mężczyzną (ur. 1986 r.) ze wsi ze Śląska północnego - niemodlińskiego, kobietą (ur. 1982 r.) ze wsi ze Śląska południowego - cieszyńskiego, oraz dwiema kobietami (ur. 1976 r. i 1984 r.) z miasta ze Śląska środkowego - okręgu gliwickiego centralnego. Badani jako osoby dorosłe opowiadali o doświadczeniach z lat szkolnych z perspektywy późniejszych doświadczeń i skutków działań pedagogicznych w ich dalszym życiu. Zgromadzony materiał badawczy analizowano pod kątem podobieństw i różnic pomiędzy narracjami ${ }^{22}$.

20 J. Bralczyk: Mówi się. Porady językowe profesora Bralczyka. Warszawa 2009, PWN.

21 D. Kubinowski: Idiomatyczność - synergia - emergencja. Rozwój badań jakościowych w pedagogice polskiej na przełomie XX i XXI wieku. Lublin 2013, Wyd. Makmed, s. 143.

22 D. Kubinowski: Jakościowe badania pedagogiczne. Filozofia - Metodyka - Ewaluacja. Lublin 2011, UMCS, s. 167. 


\section{Sytuacja edukacyjna na Górnym Śląsku}

Osoby badane dorastały w różnych środowiskach, lecz mimo to ich doświadczenia były bardzo podobne. Czynnikiem różnicującym był czas uczęszczania do szkoły (przed lub po transformacji ustrojowej) oraz pochodzenie z rodziny autochtoniczej lub napływowej (znaczące tylko w odniesieniu do pamięci o konfliktach). W wypowiedziach wyraźnie zarysowały się trzy obszary: skład zespołów klasowych, obecność gwary na lekcjach i przerwach oraz znaczenie znajomości języka polskiego w szkole oraz dalszym życiu.

\subsection{Zróżnicowanie językowe w śląskich szkołach}

Na Górnym Śląsku dialekt jest ceniony przez rdzennych mieszkańców jako wyraz odrębności kulturowej i przywiązania do tradycji ${ }^{23}$. Dla dzieci z rodzin autochtonicznych i większości rodzin mieszanych gwara jest pierwszym językiem używanym przez resztę życia w większości sytuacji komunikacyjnych. Spośród osób badanych trzy pochodziły z rodzin napływowych (przy czym jedna urodziła się w Wielkopolsce, a dwie pozostałe na Górnym Śląsku), jedna $\mathrm{z}$ rodziny mieszanej i jedna $\mathrm{z}$ autochtonicznej.

Zespoły klasowe w śląskich miejscowościach przeważnie składają się z uczniów znających gwarę w różnym stopniu:

- dzieci autochtonów często dopiero w szkole uczą się mówić po polsku, ponieważ wcześniej posługiwały się gwarą;

- dzieci urodzone na Górnym Śląsku w rodzinach napływowych znają gwarę z podwórka, a w domu porozumiewają się w języku polskim, często z naleciałościami śląskimi oraz z innych gwar, jeśli rodzina wywodzi się z kilku obszarów dialektalnych;

- dzieci z rodzin napływowych urodzone poza Górnym Śląskiem, które miejscowej gwary nie znają wcale bądź prawie wcale;

- dzieci urodzone za granicą, poznające równocześnie język polski i gwarę śląską.

23 D. Krzyżyk, H. Synowiec: O możliwościach wykorzystania wybranych metod językoznawczych $w$ badaniach nad językiem młodzieży regionów pogranicznych. W: T. Lewowicki, E. Ogrodzka-Mazur (red.): W poszukiwaniu teorii przydatnych $w$ badaniach międzykulturowych. Cieszyn 2001, Uniwersytet Śląski - Filia w Cieszynie, s. 108. 
Środowisko nauczycielskie najczęściej jest zróżnicowane językowo tak samo jak uczniowskie. Doświadczenia i obserwacje badanych potwierdzają, że postawy pedagogów wobec zachowań językowych mają duże znaczenie dla sukcesu szkolnego uczniów, ich aspiracji edukacyjnych, tożsamości, a także atmosfery w klasie. Personel pedagogiczny szkoły świadomie i nieświadomie oddziałuje na stosunek uczniów do różnorodności językowej, przekazując pozytywne lub negatywne postawy:

- wobec odrębności językowej swojej lub czyjejś,

- wobec osób, które posługują się dialektem,

- wobec osób, które z powodu braku znajomości lub własnego wyboru nie posługują się dialektem.

Oddziaływania szkoły na stosunek wychowanków do różnorodności językowej są uzależnione od polityki edukacyjnej państwa, kultury organizacyjnej szkoły oraz indywidualnych postaw nauczycieli.

\subsection{Obecność gwary w edukacji szkolnej}

Jak podkreśla wielu autorów, różnorodność kulturowa (w tym językowa) jest szansą na rozwój, ale jednocześnie grozi konfliktem. Nie inaczej jest na obszarach występowania dialektów.

Gwara jako ważny element krajobrazu kulturowego może służyć kształtowaniu poczucia przynależności do środowiska lokalnego. Podstawa programowa kształcenia ${ }^{24}$ przewiduje dla klas I-III szkoły podstawowej słuchanie baśni, opowiadań i legend z własnego regionu. Można wykorzystać tę sytuację jako okazję do poznawania słów i zwrotów gwarowych, przez co dzieci mówiące w domu po śląsku poczują się bardziej docenione. Edukacja regionalna w starszych klasach również może przybliżać gwarę. Materiałów do poznawania dialektu nie brakuje - wśród tekstów pisanych po śląsku możemy znaleźć prozę, poezję i dramat dla każdej grupy wiekowej. Ich autorzy na ogół chętnie spotykają się z dziećmi i młodzieżą szkolną. Śląską mowę słychać często podczas przedstawień z okazji Dnia Górnika (Barbórki). Szkoły włączają się też w organizację bardzo popularnych w ostatnich latach konkursów gwarowych.

24 Podstawa programowa kształcenia ogólnego dla szkół podstawowych; Załącznik nr 2 do Rozporządzenia Ministra Edukacji Narodowej z dnia 27 sierpnia 2012 r. w sprawie podstawy programowej wychowania przedszkolnego oraz kształcenia ogólnego w poszczególnych typach szkół (Dz. U. 2012, poz. 977). 
Obecność kultury śląskiej w edukacji szkolnej rodzi pytania o sytuację uczniów nieśląskich. Silna promocja dialektu może budzić wątpliwości, zwłaszcza w obliczu skrajnych ruchów separatystycznych i ideologii o podłożu ksenofobicznym. Jeśli edukacja regionalna jest prowadzona z uwzględnieniem różnorodności kulturowej środowiska szkolnego, uczniowie spoza rodzin autochtonicznych i mieszanych naturalnie włączają się w proponowane im działania - także w naukę dialektu. Jedna z badanych, urodzona w środkowej części Śląska w rodzinie napływowej, w młodszych klasach szkoły podstawowej brała udział w konkursach gwarowych, zajmując wyższe miejsca niż dzieci autochtonów. Mówienie gwarą w wybranych sytuacjach szkolnych oczywiście nie oznacza automatycznej zmiany tożsamości, podobnie jak władanie językiem francuskim nie wiąże się z przyjęciem tożsamości francuskiej.

W zróżnicowanym językowo środowisku szkolnym na ogół spontanicznie dokonuje się wymiana kulturowa i kształtuje się wspólny kod językowy umożliwiający skuteczną komunikację. Walorem edukacyjnym takiej sytuacji jest konieczność definiowania słów niezrozumiałych dla rozmówcy. Nauczyciele i wychowawcy powinni czuwać, aby naturalny proces wymiany kulturowej nie skutkował konfliktami. Cztery z pięciu osób badanych pamiętają spory wywołane nieznajomością jakiegoś słowa gwarowego, przy czym trzy z nich zauważyły, że znajomość gwary nie była wystarczającym kryterium, aby odróżnić w klasie dzieci z rodzin autochtonicznych i napływowych.

Zadaniem pedagogów jest ukazywanie dialektu jako części języka ogólnopolskiego, a regionu jako części kraju, tłumaczenie różnic oraz kształtowanie wzajemnego szacunku i zrozumienia. Odkrywanie podobieństw między różnymi dialektami sprzyja nabieraniu świadomości wspólnej historii i wspólnego dziedzictwa kulturowego. Z kolei porównywanie gwar Śląska południowego, środkowego i północnego pokazuje, że różnice nie są zaprzeczeniem jedności i wspólnoty.

\subsection{Znaczenie znajomości języka polskiego}

Kształtowanie tożsamości językowej i poczucia przynależności do regionu jest ważne, jednak szkoła odpowiada przede wszystkim za naukę poprawnej polszczyzny, na co jest położony znacznie większy nacisk w podstawie programowej kształcenia. Od znajomości języka polskiego mogą zależeć: wyniki w nauce, poczucie własnej wartości, przebieg kariery szkolnej i zawodowej, 
uczestnictwo w życiu społecznym i kulturalnym. Odczuwane niedostatki w posługiwaniu się polszczyzną odbierają pewność siebie w trakcie wystąpień publicznych, powstrzymują przed zabraniem głosu w większych grupach i w ten sposób mogą wpływać na niższą samoocenę.

Bierną znajomość polszczyzny ułatwiają bajki, opowiadania i filmy dla dzieci, natomiast umiejętności mówienia i pisania w języku polskim powinna uczyć przede wszystkim szkoła. Dla niektórych dzieci jest to jedyne środowisko, gdzie mają szansę nauczyć się swobodnego posługiwania się polszczyzną. Dotyczy to zarówno małych autochtonów, jak również dzieci przyjezdnych i urodzonych w rodzinach napływowych, które też mają naleciałości gwarowe. Podczas lekcji nauczyciel powinien zwracać uwagę na poprawne wysławianie się i prawidłową wymowę (tak u uczniów, jak i u siebie), natomiast w sytuacjach wychowawczych uczeń zawsze powinien mieć możliwość mówienia w języku, który jest mu najbliższy.

Spośród badanych tylko jedna osoba uczęszczała do szkoły podstawowej przed 1989 rokiem. W tamtym czasie nie było konkursów gwarowych, wierszy recytowanych po śląsku z okazji Dnia Górnika, elementów edukacji regionalnej w programach nauczania, lecz i wtedy znajomość dialektu odgrywała ważną rolę jako cecha różnicująca dwie grupy uczniów. Badana o wiele bardziej akcentowała w swych wspomnieniach zakaz posługiwania się gwarą w czasie lekcji: „Na przerwie każdy mówił tak, jak chciał, ale na lekcji trzeba było mówić po polsku". Opowiadała również o koleżankach, które same miały problemy z nauką języka polskiego w szkole i swoje dzieci postanowiły od urodzenia uczyć poprawnej polszczyzny. W żadnym ze znanych badanej przypadków zamiar się nie udał, gdyż dzieci wiele czasu spędzały z dziadkami rozmawiającymi gwarą.

Naukę dialektu w środowisku rodzinnym można uznać za pozytywne zjawisko międzygeneracyjnego przekazu tradycji, natomiast w szkole zbyt duża wyrozumiałość wobec gwary i gwaryzmów może zaważyć na efektach pracy dydaktycznej oraz dalszych losach życiowych jednostki.

\section{Zakończenie}

Podobieństwo wypowiedzi osób z różnych rejonów Górnego Śląska pozwala domniemywać, że badania przeprowadzone w innym regionie, gdzie ludność autochtoniczna silnie identyfikuje się z dialektem i kulturą regionalną, dałyby podobne rezultaty. 
W środowisku zróżnicowanym kulturowo szkoła powinna kształtować umiejętność „swobodnego poruszania się w dwóch lub więcej kulturach, wybierania z nich różnych elementów do konstruowania swojej tożsamości” ${ }^{25}$. Należy przy tym pamiętać, że środowiska takie „są co prawda bogatsze dzięki intensywnym kontaktom międzyetnicznym, ale jednocześnie są bardziej ofensywne, nastawione na konfrontację, a w pewnych przejawach wręcz agresywne" ${ }^{26}$. Odnosząc te stwierdzenia do terenów występowania dialektu, można przyjąć, że zadaniem szkoły jest kształtowanie podwójnej kompetencji językowej, która pozwala wykorzystywać walory środowiska zróżnicowanego kulturowo, natomiast zadaniem nauczycieli jest przede wszystkim czuwanie nad przebiegiem procesów wymiany międzykulturowej, aby różnice nie stawały się zarzewiem konfliktów, lecz były postrzegane jako cecha pozytywna, która pomaga w konstruowaniu własnej tożsamości.

Językowy aspekt sytuacji na Górnym Śląsku potwierdza, że tożsamość nie bywa nam dana, lecz jest wynikiem naszego wysiłku, ciągłych negocjacji ze sobą i interakcji z otoczeniem. Życie w takim środowisku zmusza do rozumienia i gwary, i poprawnej polszczyzny, lecz język, którym mówimy, zależy od indywidualnego wyboru - bardziej lub mniej zbieżnego z tendencjami najbliższego środowiska. Wybory językowe nie zawsze przebiegają zgodnie z podziałami etnicznymi. Negatywne doświadczenia szkolne niekiedy sprawiają, że osoby z rodzin napływowych zabiegają o to, by ich dzieci poznawały dialekt, natomiast autochtoni o naukę języka ogólnopolskiego przed rozpoczęciem przez młodsze pokolenie edukacji szkolnej.

Tak mocne przywiązanie ludności autochtonicznej do gwary jest dla szkoły wyzwaniem dydaktycznym i wychowawczym. Wykorzystanie potencjału kulturowego regionu i zróżnicowania językowego jako szansy na rozwój zależy w dużej mierze od wiedzy, umiejętności i postaw pedagogów. Doskonalenie zawodowe w tej dziedzinie jest szczególnie istotne w czasach, gdy coraz głośniej mówi się o wprowadzeniu do szkół śląskiego jako odrębnego przedmiotu. Temat ten dzieli społeczeństwo Górnego Śląska, a skutki tych podziałów z pewnością przenoszą się na grunt szkolny. Być może doświadczenia poprzednich pokoleń pomogłyby w poprawie funkcjonowania współczesnych śląskich szkół.

25 H. Rusek: Człowiek pogranicza. W: T. Lewowicki, B. Grabowska, A. Różańska (red.): Socjalizacja $i$ ksztaltowanie się tożsamości - problemy i sugestie rozwiazań. Cieszyn - Warszawa - Toruń 2008, WEiNoE UŚ, WSP ZNP w Warszawie, Wydawnictwo Adam Marszałek, s. 87.

26 Tamże, s. 86. 


\section{Bibliografia}

Bralczyk J.: Mówi się. Porady językowe profesora Bralczyka. Warszawa 2009, PWN.

Europejska Karta języków regionalnych lub mniejszościowych, sporzadzona w Strasburgu dnia 5 listopada 1992 r. (Dz. U. 2009, nr 137 poz. 1121).

Grabowska B.: Poczucie tożsamości młodzieży uczacej się w szkołach z polskim jezzykiem nauczania na Białorusi, Ukrainie iw Republice Czeskiejstudium porównawcze. Toruń 2013, Wydawnictwo Adam Marszałek.

Jasiński Z., Bryzek M.: Rola edukacji regionalnej w podtrzymywaniu tożsamości narodowej. W: Z. Jasiński, T. Lewowicki (red.): Miejsce kultur etnicznych i regionalnych w jednoczacej się Europie. Opole 2007, UO.

Konwencja ramowa o ochronie mniejszości narodowych, sporzadzona w Strasburgu dnia 1 lutego 1995 r. (Dz. U. 2002, nr 22 poz. 209).

Kożyczkowska A., Kossak-Główczewski K.: Edukacja języka i kultury na terenie Kaszub. Wybrane aspekty. W: T. Lewowicki, J. Nikitorowicz, A. Szczurek-Boruta (red.): Szkoty dla mniejszości narodowych i spoteczności kaszubskiej $w$ Polsce - stan, problemy i perspektywy. Warszawa - Cieszyn - Białystok 2013, WSP ZNP, WEiNoE UŚ, UwB, SWEM.

Krzyżyk D., Synowiec H.: O możliwościach wykorzystania wybranych metod językoznawczych $w$ badaniach nad językiem młodzieży regionów pogranicznych. W: T. Lewowicki, E. Ogrodzka-Mazur (red.): W poszukiwaniu teorii przydatnych $w$ badaniach międzykulturowych. Cieszyn 2001, UŚ Filia w Cieszynie.

Kubinowski D.: Idiomatyczność - synergia - emergencja. Rozwój badań jakościowych w pedagogice polskiej na przełomie XX i XXI wieku. Lublin 2013, Wydawnictwo Makmed.

Kubinowski D.: Jakościowe badania pedagogiczne. Filozofia - Metodyka Ewaluacja. Lublin 2011, UMCS.

Kurcz Z.: Mniejszość polska na Wileńszczyźnie. Studium socjologiczne. Wrocław 2005, UWr.

Lewowicki T., Urban J., Szczypka-Rusz A. (red.): Język, komunikacja i edukacja w społecznościach wielokulturowych. Cieszyn - Warszawa 2004, Uniwersytet Śląski w Cieszynie, Wyższa Szkoła Pedagogiczna ZNP w Warszawie.

Nikitorowicz J.: Grupy etniczne w wielokulturowym świecie. Sopot 2010, GWP. Nikitorowicz J.: Kreowanie tożsamości dziecka. Wyzwania edukacji międzykulturowej. Gdańsk 2005, GWP. 
Paleczny S.: Socjologia tożsamości. Kraków 2008, Krakowskie Towarzystwo Edukacyjne, Oficyna Wydawnicza AFM.

PAP: Tabliczki „Godomy po ślasku” niebawem w firmach, sklepach i urzędach. W: http://www.dziennikzachodni.pl/artykul/668279,tabliczki-godomy-po-slasku-niebawem-w-firmach-sklepach-i-urzedach,id,t.html (27.08.2014).

Podstawa programowa kształcenia ogólnego dla szkót podstawowych. Załącznik nr 2 do Rozporządzenia Ministra Edukacji Narodowej z dnia 27 sierpnia 2012 r. w sprawie podstawy programowej wychowania przedszkolnego oraz kształcenia ogólnego w poszczególnych typach szkół (Dz. U. 2012, poz. 977). Polański K., Jurkowski M. (red.): Encyklopedia językoznawstwa ogólnego. Wrocław 1993, Ossolineum.

Rusek H.: Człowiek pogranicza. W: T. Lewowicki, B. Grabowska, A. Różańska (red.): Socjalizacja i kształtowanie się tożsamości - problemy i sugestie rozwiazań. Cieszyn - Warszawa - Toruń 2008, WEiNoE UŚ, WSP ZNP w Warszawie, Wydawnictwo Adam Marszałek.

Rusek H.: Wspótczesne młode pokolenie jako wyzwania dla socjalizacji $i$ wychowania, W: T. Lewowicki, A. Szczurek-Boruta, B. Grabowska (red.): Przemiany społeczno-cywilizacyjne i edukacja szkolna - problemy rozwoju indywidualnego i kształtowania się tożsamości. Cieszyn - Warszawa - Kraków 2005, Oficyna Wydawnicza „Impuls”.

Sobecki M.: Kultura symboliczna a tożsamość. Studium tożsamości kulturowej Polaków na Grodzieńszczyźnie z perspektywy edukacji międzykulturowej. Białystok 2007, Wydawnictwo Uniwersyteckie „Trans Humana”. Strutyński J.: Gramatyka polska. Kraków 2002, Wyd. Tomasz Strutyński.

Szczurek-Boruta A.: Doświadczenia społeczne w przygotowaniu przyszłych nauczycieli do pracy w warunkach wielokulturowości. Cieszyn - Toruń 2013, WEiNoE UŚ, Wydawnictwo Adam Marszałek.

Szczurek-Boruta A.: Szkoła i jej rola w kształtowaniu tożsamości młodzieży. W: T. Lewowicki, W. Ogniewjuk, E. Ogrodzka-Mazur, S. Sysojewa (red.): Wielokulturowość i edukacja. Warszawa - Cieszyn - Kijów 2014, WSP ZNP, WEiNoE UŚ, Uniwersytet im. Borysa Grinczenki.

Szczurek-Boruta A.: Zadania rozwojowe młodzieży i edukacyjne warunki ich wypetniania w środowiskach zróżnicowanych kulturowo i gospodarczo. Studium pedagogiczne. Katowice 2007, UŚ.

Urlińska M. M.: Szkoła polska na obczyźnie wobec dylematów tożsamościowych. Torun 2007, UMK. 
Ustawa z dnia 6 stycznia 2005 r. o mniejszościach narodowych $i$ etnicznych oraz o jezyku regionalnym (Dz. U. 2005, nr 17 poz. 141).

Ustawa z dnia 7 września 1991 r. o systemie oświaty (Dz. U. 2004, nr 256 poz. 2572).

Valentine G., Sporton D., Nielsen K. B.: Migracja a postugiwanie się językiem: miejsca spotkań, tożsamości, przynależność. Tłum. J. Popowski, W: A. Grudzińska, K. Kubin (red.): Szkoła wielokulturowa - organizacja pracy i metody nauczania. Wybór tekstów. Warszawa 2010, Forum na rzecz Różnorodności Społecznej.

Winiarska I.: Zasięg terytorialny i podziały dialektu ślaskiego. W: http://www. gwarypolskie.uw.edu.pl/index.php?option=com_content\&task=view\&id $=854 \&$ Itemid $=19(29.08 .2014)$.

\section{Tasks of school and teachers in dialectal areas - the case of Upper Silesia}

\section{Summary}

The aim of this study is - with reference to the concept of intercultural and regional education - defining the tasks of schools and teachers in dialect areas. The article describes the linguistic ascpect of multiculturalism of Silesian schools. On the basis of pedagogical and sociological literature the author formulates a thesis that linguistic variety is richness and an opportunity for development of students and teachers, a possibility of intercultural learning, but also a cause of conflicts. Research material, which the discussion refers to, was collected by the biographical method with the use of the narrative interview technique. The results of conducted research confirmed the thesis. They allow for defining tasks of schools and teachers in dialect areas. They can also be referred to other regions, where native inhabitants strongly indentify themselves with the dialect and regional culture in general. Although the article omits the question of introducing compulsory Silesian language lessons at schools, against a background of such aspirations the undertaken subject matter seems particularly current.

Key words: the Polish language, local dialect, slang, school education, lingual identity 